\title{
FARMERS' ENTREPRENEURIAL COMPETENCIES AND TECHNICAL EFFICIENCY OF RICE FARMS
}

\author{
Olubunmi Lawrence BALOGUN *1 (iD), Abigail Gbemisola ADEYONU ${ }^{2}$ (i), Kayode AYANTOYE ${ }^{3}$
}

\begin{abstract}
Address:
${ }^{1}$ Babcock University, School of Science \& Technology, Department of Agriculture \& Industrial Technology, Road Ilishan, 121103 and Ilishan-Remo, Ogun State, Nigeria

${ }^{2}$ Landmark University, Faculty of Agriculture, Department of Agricultural Economics and Extension, Road Omu-Aran, 370102 and Omu-Aran, Kwara State, Nigeria

${ }^{3}$ Kwara State University, Faculty of Agriculture \& Veterinary Medicine, Department of Agricultural Economics and Extension, Ilorin Jebba Road Ilorin, 23431 and Malete Ilorin, Kwara State, Nigeria

* Corresponding author: blarrybunmi@gmail.com
\end{abstract}

\begin{abstract}
Research background: Rice (Oriza sativa) is a staple food in most homes in Nigeria, its demand has not been able to cope favourably well with the production. Efforts to develop and improve the production of the crop in the country were seriously curtailed due to inefficiency in the use of available resources.

Purpose of the article: The study set to determine the effects of farmers' entrepreneurial competencies (ECs) on technical efficiency (TE) of rice farms in South-west, Nigeria. Also, the study was trying to profile the socioeconomic characteristics of rice farmers and identifying their ECs in order to describe the determinants of technical efficiency of rice farms.

Methods: A multistage sampling technique was employed to select 504 respondents from which information on their socioeconomic characteristics, their ECS' variables and input-output variables were collected. The information gathered were analysed using descriptive statistics and stochastic frontier production (SFP) function (Cobb-Douglas model).

Findings \& value added: The results showed that farms were technically inefficient with a mean TE score of 0.6842 with evidence of increasing returns to scale. The results of the Maximum-likelihood Estimation of the SFP model reveals that the quantity of seed planted, farm size and amount of man-day labour used significantly explained the technical efficiency of rice farms. Also, some socioeconomic factors and ECs factors such as organising and commitment were found to be responsible for rice farmers' inefficiency. The study recommends appropriate entrepreneurial training for rice farmers focussing on resource management and training the extension workers on necessary competency knowledge.
\end{abstract}

Key words: entrepreneurial competencies; farm-level; resource management; rice farms JEL Codes: C67; D13; D24; D61

\section{INTRODUCTION}

Rice (Oriza sativa) is a cereal crop of high nutritional value. About 80 per cent of calorie requirements of consumers' need worldwide are derived from rice and consumptions of the product has no cultural, religious, ethnic or geographical boundary (Inuwa et al., 2011). It is one of the important grains in Nigeria, not only on the basis of the number of farmers that cultivated the crop but also in its economic value. It is a staple food in most homes and its demand has not been able to cope favourably well with production (Bamiro and Aloro, 2012). It is cultivated and consumed in all ecological zones of Nigeria (Bamiro and Aloro, 2012; Ohaka et al., 2013; Ohajianya and Onyeweaku, 2003). It is an important food security crop in both rural and urban areas of the country (USAID 2009; Chidiebere-Mark et al., 2019). Food and Agriculture Organisation (2017) and cited in Ahmed (2020) reports that on average, rice consumption per person stood at $24.8 \mathrm{~kg} / \mathrm{annum}$, signifying 9 per cent of the total calorie of food intake in Nigeria. The annual consumption of milled rice of over 5.5 million metric tonnes surpasses domestic production of 3.3 million metric tonnes (Federal Ministry of Agriculture and Rural Development (FMARD), 2013; Ogunsumi et al., 2013). The demand-supply gap has been attributed to increased population and urbanisation, and this has resulted in some significant importation of milled rice (Bamiro and Aloro, 2012; USDA, 2018; Ahmed, 2020). Given the importance of rice as a food security crop in Nigeria, efforts are being made to ensure that the whole rice food system remains active and efficient (Oteh et al., 2018). A number of policies were put in place by various governments to boost local production and reduce importation. For instance, in 2004, the Presidential Initiative in Agriculture (PIA) was 
launched to increase the production and utilization of rice and three other crops. Other policies include the Agricultural Transformation Agenda (ATA) in 2010 and also in 2015, Agricultural Promotion Policy (APP) aimed at unlocking Nigeria's agricultural potential and solve the underlying challenges in its agricultural system. Despite all these efforts, agricultural productivity in Nigeria was seriously curtailed by inefficiency in the use and allocation of resources (Balogun and Obi-Ogbedi, 2012). Efficiency measurement is very vital because it is a determinant in output growth (Al-Hassan, 2012). It is referred to as how productive a firm can be, given the minimal resources required to do the job. Across all economic sectors, the business (farming inclusive) the environment provides opportunities for entrepreneurial success (Kuratko and Audretsch, 2009; Xaba, 2014). Entrepreneurship enhances the efficiency of people and resources, and ultimately, increases people's income (Fortunato, 2014; Ataeia et al., 2020). Entrepreneurship is a new situation for farmers to combine the various available resources in the farms efficiently, which then enables them to be successful (Bergevoet et al., 2005). This is because farmers are faced with challenges that require taking decisions and putting his managerial competencies to action (Norton et al., 2014). It is therefore evident that ECs are required by farmers to make sound farm decisions that can lead to efficiency in production. The improvement in the performance of family farm enterprises lead to increased food production, raises farmer's income and improves the standard of living of people (Adofu et al., 2013; Afolami et al., 2015)

\section{Theoretical framework and literature review}

Theoretically, Resource-based view was utilized to explain the effects of ECs on the resource allocation capabilities of farms (Barney, 1991). The theory is premised on the value addition which permits entrepreneurs to acquire, develop and mobilize resources more efficiently (Tehseen and Ramayah, 2015). Undoubtedly, ECs are interconnected to an entrepreneur's skills' capabilities, and knowledge as intangible and prized resources that can add to enterprise success in terms of output (Tehseen and Ramayah, 2015). In the perspective of this study, the resource-based view was relevant in explaining the survival of farm which depends on endowed resources and how it can utilize these endowments to improve production output on a sustainable basis (Nabiswa and Mukwa, 2017). According to Sher et al. (2019) farmers' entrepreneurial skills are the essential elements required for enhanced performance in terms of potential market location and prompt delivery of food commodities. However, Sinyolo and Mudhara (2018) opine that some levels of entrepreneurship skills and competencies could possibly improve production output among the farming households and hence impacts food security. As opined by Nieuwoudt et al., (2017), each of the respondent's ECs directly influenced the operating efficiency of the farm as indicated by Data Envelopment Analysis (DEA). Measuring the economic performance of a farm needs an understanding of production decisions and the TE levels. Technical Efficiency which is a prerequisite for economic efficiency secures the economic feasibility and sustainability of a farm (Ahmadzai, 2017). Entrepreneurial competencies of farmers are vital in improving farmers' yield for sustainable agricultural development through improved family food and income security. Entrepreneurial competencies empower farmers to have access to better markets with better products that gave them higher prices, resulting in increased incomes (Opolot et al., 2018; Arellano and Delos Reyes 2019). Various studies (Jordaan and Grové, 2012; Nieuwoudt, 2016; Ataeia et al., 2020) in developing countries have shown that entrepreneurial skills impact the TE of smallholder's farms. The realisation of goals of any business (farming business inclusive) depends heavily on the manager's ECs that is translated into efficiency in production (Nasuredin et al., 2016; Umar et al., 2019). Presently, the economy of countries worldwide is adversely affected by the COVIDS-19 pandemic; leading to a shortage of food supplies. The situation has led to the need for increased food production especially a staple crop like rice. Thus, this study set to determine the effects of farmers' entrepreneurial competencies on technical efficiency of rice farms in South-west, Nigeria.

\section{DATA AND METHODS}

Study Area: The study was conducted in South-west, Nigeria. It is characterized by a usually equatorial climate with distinct dry and wet seasons. The wet season lasts for about seven months all things being equal, with rainfall which ranges between $1200 \mathrm{~mm}$ and $2600 \mathrm{~mm}$. The mean rainfall is $1480 \mathrm{~mm}$ with an average monthly temperature of $18^{\circ} \mathrm{C}-24^{\circ} \mathrm{C}$ and $30^{\circ} \mathrm{C}-35^{\circ} \mathrm{C}$ during the raining and dry seasons respectively. The planting season usually lasts for nine months with a peak around July and September. South-west is comprised of four distinct sub-ecologies which are moist and dry lowland forest, swamp mangrove forest and savannah, savannah mosaic and woodland forest and all have soil with low to medium productivity potential. Main crops grown in the area include cassava, cowpea, cashew, citrus, cocoa, coffee, kolanut, maize, millet, oil palm, rice, and sorghum. The choice of southwest geo-political zone Nigeria was based on the fact that it is found along forest zones and guinea/derived savannah within the rainforest belt of Nigeria. A multistage sampling procedure was employed for the study. In the first stage, two major rice-producing states were purposely chosen based on the past production records. The second stage of the sampling involved the purposive selection of seven Local Government Areas (LGAs) from selected states known for rice production. The stage that followed was the random selection of villages within the selected LGAs using probability proportionate to the number of villages in each of the selected LGAs. At the fourth stage, 15 farmers were purposely selected from each of these villages based on the proportion of rice production activities. A total of 600 rice farmers were randomly selected from 16 identified villages/communities in the two states. However, 84 percent of the respondents' responses with complete information were analysed for this study. Data were collected on socio-economic characteristics of rice farmers, their ECs' variables 
(Opportunity, Relationship, Conceptual, Organising, Strategic and Commitment), input-output variables data such as quantities of land, seed, fertilizer, herbicides, pesticides, labour used (family and hired), the number of production outputs for 2018/2019 farming season. The researchers adopted the ECs instrument earlier developed by Man $\boldsymbol{e t}$ al., (2008) to examine the ECs levels of rice farmers. This instrument was chosen because of its high level of reliability for measuring ECs from a behavioural standpoint. The instrument consists of six constructs with a varying number of items. In all, there were 53 items related to the abilities of individual respondents, but we considered only 40 of the items which relate to the agricultural sector. The items are answered with a 7-point Likert scale ranging from 1 which represents "very strongly disagreeing' to 7 which is 'strongly agreeing'. The result of reliability or internal consistency shows that the Cronbach's Alpha coefficients of all the variables were higher than 0.70. The result agrees with Hair et al., (2014) that considered Cronbach's alpha value higher than 0.7 as good and reliable.

\section{Method of Data Analysis}

Data were analysed with descriptive statistics and principal component (using IBM SPSS version 21 statistical software program) and stochastic frontier production model (using FRONTIER 4.1c). The ECs levels of the rice farmers were determined using a Principal Component Analysis (PCA). The PCA is a statistical data reduction methods employed to examine the linear correlations among a set of variables. It can be used for the detection of underlying dimensions in a set of variables (Pishie 2009; Mensah and Dadzie 2020). The value of the $\mathrm{i}^{\text {th }}$ principal component can be compactly calculated using the expression specified by Field (2005) and adopted by (Yankah 2015). The model is specified as Equation (1-2).

$$
\begin{aligned}
& P C i=\sum_{j=1}^{p} K_{j} X_{j} \\
& P C i=K_{i 1} X_{i}+K_{i 2} X_{2}+K_{i 3} X_{3}+\cdots+K_{i p} X_{p}
\end{aligned}
$$

Where:

$K_{i j}$ factors and $X_{j}$ marks received from each of entreprenurial competencies parameters. In this equation, $i=1,2,3, . .6$ denotes each of the entrepreneurial competencies variables while $j=1,2,3,4, \ldots \mathrm{p}$

\section{Stochastic Frontier Production Function (SFP)}

The SFP function proposed by Aigner et al., (1977) and adopted by Krasachat (2017) was used to measure the Technical Efficiency (TE) of farms. The function is stated as Equation (3).

$Y=f\left(G_{i j} \beta\right)+\epsilon_{i}$

Where: $\epsilon_{i}=V_{i}-U_{i}$

$Y$ Output in tons/ha

$G_{i}$ input used $(j=1,2,3 \ldots \ldots n)$

$\beta_{\mathrm{i}}$ is a vector of the unknown parameters

$\epsilon_{i}$ error term which consists of $V_{i}$ and $U_{i}$
The distribution of the two error term components $V_{i}$ and $U_{i}$ are assumed to be independent of one another. The error term $V_{i}$ allows for random variation of the production function between different farms and it also considers factors which are beyond the farmers' control (Krasachat, 2017). The error term $U_{i}$ depicts the TE in relation to the frontier. A $U_{i}$ of 0 , implies that production lies on the frontier, while a $U_{i}>0$, signifies production that lies below the frontier which simply means inefficiency. It then follows from Equation (4).

$\sigma_{s}^{2}=\sigma_{u}^{2}+\sigma_{v}^{2}$

Where:

$\Upsilon=\frac{\sigma_{u}^{2}}{\sigma_{v}^{2}}$

The TE of a farmer is expressed as the expected values of $V_{i}$ conditional on $\epsilon_{i}=V_{i}+U_{i}$ (Jondrow et al., 1982) (Equation 5).

$$
E\left(U_{i} / \epsilon_{i}\right)=\sigma_{s,}\left\{\frac{\Phi \frac{\epsilon_{i} \mu}{\sigma_{S}}}{1-\Phi \frac{\epsilon_{i} \mu}{\sigma_{S}}}+\frac{\epsilon_{i} \mu}{\sigma_{s}}\right\}
$$

Where:

$E$ Expectation of the farm owner

$\Phi$ Standard normal density function.

Then, $T E$ is measured such that $0 \leq T E \leq 1$ (Equation $6)$.

$$
T E_{i}=\exp \left\{-E\left({ }^{U_{i}} / \epsilon_{i}\right\}\right.
$$

The measurement of TE and its underlying factors are of critical significance in production theory. The TE of a farm and the extent of use of inputs, determine the output and capacity utilization. Detecting the various factors influencing it allows stakeholders to take suitable measures to improve on it. The TE model was jointly analysed with stochastic frontier function with a singlestage maximum likelihood estimation technique. The SFP version employed in this study is Cobb-Douglas. The model is capable of estimating both the technical efficiency and technical inefficiency jointly with a singlestage maximum likelihood estimation procedure.

The technical efficiency function (Equation 7).

$\ln Y_{i}=\beta_{0} \ln +\beta_{1} \ln H_{1}+\beta_{2} \ln H_{2}+\beta_{3} \ln H_{3}+\beta_{4} \ln H_{4}+$ $\beta_{5} \ln H_{5}+\beta_{6} \ln H_{6}+V_{i}-U_{i}$

Where:

In natural logarithms;

$Y_{i}$ Output of the rice farm i (ton/ha);

$H_{1}$ Quantity of seed in $\mathrm{kg}$;

$\mathrm{H}_{2}$ Farm size in hectare;

$\mathrm{H}_{3}$ Quantity of fertilizer in kilogram;

$\mathrm{H}_{4}$ Quantity of herbicide in litre;

$\mathrm{H}_{5}$ Quantity of pesticide used in litre;

$H_{6}$ Amount of labour (man-days);

$\beta_{s}$ Unknown parameters; 
$V_{i}$ Random errors which capture random effect;

$U_{i}$ Technical inefficiency effect;

$i$ Individual rice farm as earlier defined;

The technical inefficiency function (Equation 8).

$E\left(U_{i} / \epsilon_{i}\right)=\sigma_{s,}\left\{\frac{\Phi \frac{\epsilon_{i} \mu}{\sigma_{S}}}{1-\Phi \frac{\epsilon_{i} \mu}{\sigma_{S}}}+\frac{\epsilon_{i} \mu}{\sigma_{s}}\right\}$

Where:

$U_{i}$ Level of technical inefficiency of individual rice farm;

$G_{1}$ Age of the farmer (years);

$G_{2}$ Sex of farmer $($ Male $=1$, Female $=0)$;

$G_{3}$ Years spent in school of farmers (Years);

$G_{4}$ Farmer's years of experience in rice farming (Years;)

$G_{5}$ Association membership of farmer (Yes $=1,0$ otherwise);

$G_{6}$ Opportunity competencies;

$G_{7}$ Relationship competencies;

$G_{8}$ Conceptual competencies;

$G_{9}$ Organizing competencies;

$G_{10}$ Strategies competencies;

$G_{11}$ Commitment competencies;

$\mathcal{E}_{i}$ Error term.

\section{RESULT AND DISCUSSION}

Summary of the descriptive statistics of some variables

Table 1 presents a summary of the descriptive statistics of some variables of interest. The results show that an average of about 1.66 tonnes/hectare of rice paddy was produced per farm, while the average farmland cultivated to rice stood at 1.94 hectares. The result of rice productivity was a little lower than the average national yield of rice which stood at 1.8 tonnes per hectare (FAOSTAT, 2013). The result disagrees with Ajah and Ajah (2014) that on average, rice farms produce about 1.348 tonnes of paddy rice from 1.84 ha of farmland in the country. The result reveals that the farmers planted approximately $120.5 \mathrm{~kg} / \mathrm{ha}$ paddy rice seed and used $85.21 \mathrm{~kg} / \mathrm{ha}$ of fertilizer in their farms. With regard to the usage of herbicides and pesticides, the results show that an average of 12.14 litres and 1.85 litres respectively were used. The total amount of man-days labour used varied from farm to farm depending on tools used, the land area planted to rice, and the number and quality of labourers and also the type of activities to be done. However, farms utilized an average of 148 man-days of labour in their farms. Farmer's age and his/her productive capability and hence, output, are correlated (Adeyonu et al., 2019). It determines the farmer's productive ability and consequently, his output. The mean age of the farmers was 44 years. This result shows that most rice farmers were in their active age and perceived entrepreneurial skills are acquired over time. Furthermore, the result shows that about three-quarter of the respondents are male, while the rest are females. This is an indication that the proportion of females in rice farming is low and this calls for concerted efforts which aim at empowering women to increase their participation in rice farming. The result shows that the mean years of experience of farmers in rice farming was almost 16 . The Table 1 depicts that the respondents had attended school for about 14 years on average. Acquisition of education by farmers would enable them to know how to seek new farm practices and subsequently apply them in their farms. About two-thirds of the farmers belong to the rice growers' association and had participated in entrepreneurial training.

\section{Entrepreneurial competencies of rice farmers}

Kaiser-Meyer-Olkin measure of sampling adequacy (KMO) and Bartlett's test of sphericity is presented in Table 2. Of the 4 items each that were listed under opportunity and commitment competencies only 1 and 2 factors respectively were extracted. Also, 11 and 7 items listed under organizing and conceptual competencies, 3 factors were extracted in each of them while in the relationship and strategic competencies with 6 and 8 items, only 1 and 2 items respectively that loaded significantly on the factors were extracted. All the extracted ECs variables tested for adequacy were significant and used for further analysis. The values of the Kaiser-Meyer-Olkin measure of sampling adequacy (KMO) ranged between 0.626-0.887, while the values of the Bartlett test were all significant at $\mathrm{P}<0.01$.

Estimates of the parameters of stochastic frontier production function of rice farms

Table 3 presents the maximum likelihood estimates of the parameters of the SFP model. The SFP model depicted increasing returns to scale. The results reveal that the quantity of seed planted, farm size, and amount of manday labour were the variables that significantly explained the TE of rice farms. The quantity of seed planted had a positive coefficient which implies that a unit increase in the variable increased the TE of rice production by 22.2 percent. This could be attributed to improved transplanting practice by transplanting bunches of seedlings with the intention of increasing the yield through the population. The result corroborates the submission of Arellano and Delos Reyes (2019) who posited that increasing land utilization would increase rice production. The number of labour employed in the rice farm has an indirect association with TE with a coefficient of 0.05 . This is a pure case of overutilization of labour in rice production which was already in stage 3. The result is similar to that of Arellano and Delos Reyes (2019) who found that many rice farmers depended more on their family labour for farm operation needs because they do not have enough incentives to hire skilled labour, hence; quality and yield of their farm work are adversely affected. Furthermore, the authors found that age and technical inefficiency are directly related, meaning that a unit increase in farmer's age, will increase the likelihood of farms' inefficiency level by almost 6 percent ceteris paribus. This result is in consonance with the submission of Otuaniya et al., (2015) who revealed that farmer's age and farm's level of inefficiency are positively correlated. 
Table 1. Summary of descriptive statistics of some variables of interest

\begin{tabular}{|c|c|c|c|c|}
\hline Variable & Mean & Std. dev. & Min. & Max. \\
\hline Output of rice & 1.66 & 0.97 & 0.10 & 3.11 \\
\hline Quantity of seed & 120.51 & 15.89 & 50.00 & 200 \\
\hline Farm size cultivated & 1.94 & 0.60 & 0.19 & 3.00 \\
\hline Quantity of fertilizer & 85.22 & 81.39 & 0 & 300 \\
\hline Quantity of herbicide & 12.15 & 3.02 & 0 & 18 \\
\hline Quantity of pesticide & 1.85 & 0.25 & 0 & 4 \\
\hline Amount of labour & 148.37 & 30.94 & 15.01 & 350.11 \\
\hline Age of the farmer & 43.97 & 8.88 & 22 & 66.0 \\
\hline Sex of farmer $($ Male $=1$, Female $=0)$ & 0.76 & 0.34 & 0 & 1 \\
\hline Years of schooling & 13.52 & 2.94 & 0 & 15 \\
\hline Years of experience in rice farming & 15.95 & 4.57 & 2 & 35 \\
\hline Association membership (Yes $=1,0$ otherwise) & 0.61 & 0.23 & 0 & 1 \\
\hline Participation in Entrepreneurial Training(Yes $=1,0$ otherwise) & 6.01 & 2.21 & 0 & 10 \\
\hline
\end{tabular}

Source: Field Survey, 2019

Table 2. Kaiser-Meyer-Olkin Measure of Sampling Adequacy and Bartlett's Test of Sphericity

\begin{tabular}{lllllrr}
\hline Entrepreneurial competence & No of items & $\begin{array}{l}\text { No of Extracted } \\
\text { items (factors) }\end{array}$ & Determinant & KMO & $\begin{array}{l}\text { Bartlett } \\
\text { Chi square }\end{array}$ & Sig. \\
\hline Opportunity & 4 & 1 & 0.48 & 0.63 & 369.22 & 0.00 \\
Relationship & 6 & 1 & 0.10 & 0.80 & 1131.63 & 0.00 \\
Conceptual & 7 & 3 & 0.17 & 0.64 & 890.72 & 0.00 \\
Organizing & 11 & 3 & 0.00 & 0.75 & 3797.27 & 0.00 \\
Strategic & 8 & 2 & 0.01 & 0.89 & 2338.09 & 0.00 \\
Commitment & 4 & 2 & 0.40 & 0.70 & 458.05 & 0.00
\end{tabular}

Source: Authors' estimates.

Table 3: Maximum likelihood estimates of the parameters of the stochastic frontier production function of rice farmers.

\begin{tabular}{|c|c|c|c|c|}
\hline Variable & Parameter & Coefficient & Std. error & t-ratio \\
\hline Constant & $\beta_{0}$ & $2.67 * * *$ & 0.25 & 10.52 \\
\hline In $H_{1}$ & $\beta_{1}$ & $0.22 * *$ & 0.10 & 2.35 \\
\hline In $\mathrm{H}_{2}$ & $\beta_{2}$ & $1.27 * * *$ & 0.07 & 18.32 \\
\hline In $\mathrm{H}_{3}$ & $\beta_{3}$ & 0.01 & 0.01 & 0.77 \\
\hline In $\mathrm{H}_{4}$ & $\beta_{4}$ & -0.01 & 0.02 & -0.37 \\
\hline In $H_{5}$ & $\beta_{5}$ & 0.02 & 0.02 & 0.90 \\
\hline In $\mathrm{H}_{6}$ & $\beta_{6}$ & $-0.05 * * *$ & 0.02 & -2.56 \\
\hline \multicolumn{5}{|l|}{ Inefficiency } \\
\hline Constant & $\lambda_{0}$ & $0.61 * *$ & 0.27 & 2.27 \\
\hline$G_{1}$ & $\lambda_{1}$ & $0.06 *$ & 0.03 & 1.96 \\
\hline$G_{2}$ & $\lambda_{2}$ & 0.04 & 0.03 & 1.43 \\
\hline$G_{3}$ & $\lambda_{3}$ & $-0.09 * * *$ & 0.02 & -4.80 \\
\hline$G_{4}$ & $\lambda_{4}$ & -0.02 & 0.04 & -0.56 \\
\hline$G_{5}$ & $\lambda_{5}$ & $0.07 *$ & 0.04 & 1.93 \\
\hline$G_{6}$ & $\lambda_{6}$ & -0.04 & 0.03 & -1.59 \\
\hline$G_{7}$ & $\lambda_{7}$ & -0.01 & 0.01 & -0.21 \\
\hline$G_{8}$ & $\lambda_{8}$ & -0.01 & 0.05 & -0.02 \\
\hline$G_{9}$ & $\lambda_{9}$ & $-0.02 * *$ & 0.01 & -2.35 \\
\hline$G_{10}$ & $\lambda_{10}$ & 0.01 & 0.01 & 0.63 \\
\hline$G_{11}$ & $\lambda_{11}$ & $0.26 * * *$ & 0.04 & 6.85 \\
\hline Sigma-squared & $\sigma_{s}^{2}=\sigma_{u}^{2}+\sigma_{v}^{2}$ & $0.16 * * *$ & 0.01 & 15.10 \\
\hline Gamma & $\Upsilon=\frac{\sigma_{u}^{2}}{\sigma_{s}^{2}}$ & $0.02 * * *$ & 0.10 & 0.14 \\
\hline Log-likelihood & -254.350 & & & \\
\hline
\end{tabular}

LR test of the one-sided error 63.325

Note: $* * *$ and $* * *$ represent $0.1,0.05$ and 0.01 levels of significant respectively.

Source: Field Survey, 2019. 
Table 4: Distribution of Technical Efficiency of levels of rice farms

\begin{tabular}{lrr}
\hline TE Score & Frequency & $\%$ \\
\hline$<0.50$ & 8 & 1.58 \\
$0.50-0.59$ & 96 & 19.05 \\
$0.60-0.69$ & 196 & 38.89 \\
$0.70-0.79$ & 138 & 27.39 \\
$0.80-0.89$ & 57 & 11.31 \\
$>0.90$ & 9 & 1.78 \\
Total & 504 & 100.0 \\
Minimum & 0.42 & \\
Maximum & 0.95 & \\
Mean & 0.68 & \\
\hline Source
\end{tabular}

Source: Field Survey, 2019.

A unit increase in the level of organizing competence resulted in a reduction in the level of inefficiency of rice farms by 1.6 percent. This perhaps may be unconnected with the fact that farmers with a high level of organizing efficiency were able to organize their resources through team building which resulted in effective management of those resources, and hence, better management. This submission is in support of those of Scuotto et al. (2017) and Shih and Tsai (2016) who indicated that good knowledge of resources management in business enables innovation and organizational success. Likewise, commitment competence had a positive influence on rice farms' level of inefficiency. The result indicates that a unit increase in commitment competence led to an increase in the likelihood of the level of technical inefficiency by 26.4 percent. The result supports Sambasivan et al., (2010) and Rajabi et al., (2018) who posited that a high level of commitment and hard and hard work by entrepreneurs determined the achievement of the goal of the enterprise.

\section{Frequency distribution of levels of technical efficiency} of rice farms

The distribution of efficiency estimates of rice farms is presented in Table 4. The mean TE score of farms is 68.42 percent is an indication that all the farms operated at moderate levels of efficiency at the given rice production techniques adopted by the farm owners. Howbeit, the value of the average TE is an indication that the output realized can still be increased by about 32 percent through the adoption of the techniques of the most efficient farm.

The year of schooling is another important determinant of farm's inefficiency which stood at 9 percent and significant at 0.01 level. It implies that years of schooling had a reducing effect on rice farms' inefficiency in the south-west, Nigeria. This can be understood because trained farmers are early adopters of improved technology that can increase their productivity. Membership of the association of rice farmers has a positive and significant relationship with technical inefficiency. Rice farmers' membership in the association increased their technical inefficiency by 7 percent. This might be as a result of farmers' devoting more time to association matter to the detriment of their farm work. Also, the analysis shows that organizing competency and technical inefficiency were negatively related.

\section{CONCLUSIONS AND RECOMMENDATIONS}

This study focused on the entrepreneurial competencies of rice farmers and the level of technical efficiency of rice farms in the south-west, Nigeria. The study found that efficient use of resource coupled with entrepreneurial competencies (good organisational ability and commitment to success by rice farmers) enhance the level of technical efficiency of farms. The mean technical efficiency score implied that farms are not operating at the optimum production frontier indicating that there is still a substantial potential available to farmers to increase their output given the present technologies and inputs. The stochastic frontier production function depicted increasing returns to scale. The study also identified organisational and commitment competencies as determinants of technical inefficiency among the rice farmers. It is suggested that various stakeholders in the rice value chain (government and private agencies) should design an appropriate training programme that will focus on entrepreneurial training for rice farmers. Also, there is a need for networking by rice farmers as a means of sharing experience and this should be complemented with short term training on resources management by extension agents. Reflecting on the sustainable agriculture and rural development, the study has brought to light, that the future of farmers' can only be guaranteed if they become more entrepreneurial in the way they manage their farms as a business.

\section{REFERENCES}

ADOFU, I., SHAIBU, S. O., \& YAKUBU S. (2013). The Economic impact of improved agricultural technology on cassava productivity in Kogi State of Nigeria. International Journal of Food and Agricultural Economics, $\quad 1(1)$ 63-74. https://www.foodandagriculturejournal.com/63.pdf

ADEYONU, A. G., BALOGUN, O. L., AJIBOYE, B. O., OLUWATAYO, I. B., \& OTUNAIYA, A. O. (2019). Sweet potato production efficiency in Nigeria: Application of Data Envelopment Analysis. AIMS Agriculture and Food, 4(3). 672-684. https://www.aimspress.com/article/doi/10.3934/agrfo od.2019.3.672

AFOLAMI, C. A., OBAYELU, A .E., \& VAUGHAN, I.I. (2015). Welfare impact of adoption of improved 
cassava varieties by rural households in South Western Agricultural and Food Economics, 3(18). https://doi.org/10.1186/s40100-015-0037-2

AL-HASSAN, S. (2008). Technical efficiency of rice farmers in Northern Ghana, AERC Research Paper 178. https://ideas.repec.org/p/aer/wpaper/178.html

AL MAMUN, A., FAZAL, S. A., \& MUNIADY, R. (2019). Entrepreneurial knowledge, skills, competencies and performance: a study of microenterprises in Kelantan, Malaysia, Asia Pacific Journal of Innovation and Entrepreneurship, 13(1). 29-48.

https://www.emerald.com/insight/content/doi/10.110 8/APJIE-11-2018-0067/full/html

AHMADZAI, H. (2017). Crop diversification and technical efficiency in Afghanistan: stochastic frontier analysis, CREDIT Research Paper, No. 17/04, The University of Nottingham, Centre for Research in Economic Development and International Trade (CREDIT), Nottingham. https://www.nottingham.ac.uk/credit/documents/pape rs/2017/17-04.pdf

AHMED, M.A. (2020). Profitability and socio-economic analysis: evidence from rice production in Lake Geriyo of Adamawa State, Nigeria. FUW Trends in Science \& Technology Journal, 5(2), 360-363. http://www.ftstjournal.com/Digital\%20Library/52\%2 0Article\%208.php

AIGNER, D. J., LOVELL, C. A. K., \& SCHMIDT, P. (1977). Formulation and estimation of stochastic frontier production function models, Journal of Econometrics, 6(1), 21-37. http://dx.doi.org/10.1016/0304-4076(77)90052-5

AJAH, J., \& AJAH, F. C. (2012). Socioeconomic determinants of small scale rice farmers' output in Abuja. Asian Journal of Rural Development, 4(1),1624. https://dx.doi.org/10.3923/ajrd.2014.16.24

ARELLANO, C. A., \& DELOS REYES, J. A. (2019). Effects of farmer-entrepreneurial competencies on the level of production and technical efficiency of rice farms in Laguna, Philippines. J. ISSAAS 25, 45-57. http://issaasphil.org/wp-content/uploads/2019/11/5.Arellano Delos-Reyes-2019entrepreneurial competencies-FINAL.pdf

ATAEIA, P., KARIMI, H., GHADERMARZIC, H., \& NOROUZID, A. (2020). A conceptual model of entrepreneurial competencies and their impacts on rural youth's intention to launch SMEs. Journal of Rural Studies, 75, 185-196. https://doi.org/10.1016/j.jrurstud.2020.01.023

BALOGUN, O. L., \& OBI-EGBEDI, O. (2012). Resource use efficiency and productivity of cocoa farmers in Idanre LGA of Ondo State, Nigeria. American Journal of Social and Management Sciences, 3, 60-67. $\underline{\text { 10.5251/AJSMS.2012.3.2.60.67 }}$

BAMIRO, O. M., \& ALORO, J. O. (2013). Technical efficiency in swamp and upland rice production in Osun State. Scholarly Journal of Agricultural Science, 3(1), 31-37.

BARNEY, J. (1991). Firm resources and sustained competitive advantage. Journal of Management, $17(1)$, 99-120. https://journals.sagepub.com/doi/10.1177/014920639 101700108

BERGEVOET, R. H. M., GIESEN, G. W. J., SAATKAMP, H. W., VAN WOERKUM, C. M. J., \& HUIRNE, R. B. M. (2005). Improving entrepreneurship in farming: the impact of a training programme in Dutch Dairy Farming. Invited Paper Presented at the 15th Congress of the International Farm Management Association (IFMA), Developing Entrepreneurship Abilities to Feed the World in a Sustainable Way. Campinas, Brasil, August 14 to 19, 2005.

http://ageconsearch.umn.edu/bitstream/24219/1/cp05 be02.pdf

CHIDIEBERE-MARK, N., OHAJIANYA, D., OBASI, P., \& ONYEAGOCHA, S. (2019). Profitability of rice production in different production systems in Ebonyi State, Nigeria, Open Agriculture, 4(1), 237-246. https://doi.org/10.1515/opag-2019-0022

FEDERAL MINISTRY OF AGRICULTURE AND RURAL DEVELOPMENT (FMARD). (2013). Agricultural transformation agenda (ATA) 2013 score card. Federal ministry of agriculture and rural development, Nigeria. $\quad$ From https://www.fmard.gov.ng

FIELD, A. (2005), Discovering statistics using SPSS. 2nd Edition. Sage, London.

FAO. (2017). A Database of the food and agriculture organisation of the United nations (FAO). http://faostat.fao.org. (Retrieved on 11 May 2019).

FORTUNATO, M. W. P. (2014). Supporting Rural entrepreneurship: a review of conceptual developments from research to practice. Community Development, 45(4), 387-408, 387-408. https://doi.org/10.1080/15575330.2014.935795

HAIR, J. F., SARSTEDT, M., HOPKINS, L., \& KUPPELWIESER, V. (2014). Partial least squares structural equation modeling (PLS-SEM) An Emerging Tool in Business Research. European Business Review, 26(2), 106-121. http://dx.doi.org/10.1108/EBR-10-2013-0128

INUWA, I. M. S., KYIOGWOM, U. B., ALA, A. L., MAIKASUWA, M. A., \& IBRAHIM, N. D. (2011). Profitability analysis of rice processing and marketing in Kano State, Nigeria. Nigerian Journal of Basic and Applied Science, 293298. https://www.ajol.info/index.php/njbas/article/view/73 $\underline{902}$

JONDROW, J., LOVELL, C. A. K., MATEROV, I. S., \& SCHMIDT, P. (1982). The estimation of technical inefficiency in the stochastic frontier production function model. Journal of Econometrics, 19(2-3), 233 - 238. https://doi.org/10.1016/0304-4076(82)90004-5

JORDAAN, H., \& GROVÉ, B. (2012). An economic analysis of the contribution of water use to value chains in agriculture (No 1779/1, p. 12). WRC Report. http://ifmaonline.org/wpcontent/uploads/2015/12/15 Jordaan_etal_2_P180188.pdf

KRASACHAT, W. (2017). Technical inefficiency of chili farms in Thailand. Contributed paper prepared for presentation at the $91^{\text {st }}$ Annual Conference of the 
Agricultural Economics Society, the Royal Dublin Society, Dublin, Ireland. April 24 to 26, 2017.

KROPPD, F. and LINDSAY, N. J. (2001). South African Business Dynamics: Measuring entrepreneurship, Journal of African Business 2(1), 23-45. https://doi.org/10.1300/J156v02n01_03

KURATKO, D. F., \& AUDRETSCH, D. B. (2009). Strategic Entrepreneurship: Exploring Different Perspectives of an Emerging Concept. Entrepreneurship Theory and Practice, 33(1), 1-17. https://doi.org/10.1111/j.1540-6520.2008.00278.x

MAN, T.W.Y., LAU, T., \& SNAPE, E. (2008). Entrepreneurial competencies and the performance of small and medium enterprises: An investigation through a framework of competitiveness, Journal of Small Business \& Entrepreneurship, 21(3), 257-276, https://doi.org/10.1080/08276331.2008.10593424

MCELWEE, G. (2006). Farmers as Entrepreneurs: Developing Competitive Skills. Journal of Developmental Entrepreneurship, 11(3), 187-206. https://www.academia.edu/252528/Farmers_As_Entr epreneurs_Developing_Competitive_Skills

MENSAH, A. C., \& DADZIE, J. (2020). application of principal component analysis on perceived barriers to youth entrepreneurship. American Journal of Theoretical and Applied Statistics, 9(5), 201-209. https://doi:10.11648/j.ajtas.20200905.13

NABISWA, F., \& MUKWA, J. S. (2017). Impact of credit financing on human resource development among micro and small enterprises: a case study of Kimilili Sub County, Kenya. Asian Journal of Management Science and Economics, 4(1), 43-53. http://www.multidisciplinaryjournals.com/wpcontent/uploads/2017/01/Full-Paper-IMPACT-OFCREDIT-FINANCING-ON-HUMAN-RESOURCEDEVELOPMENT.pdf

NASUREDIN, J., HALIPAH, A., \& SHAMSUDIN, A. (2016). Entrepreneurial competency and SMEs performance in Malaysia: Dynamic capabilities as mediator. International Journal of Research, 3(14), 4759-4769.

$\underline{\text { http://edupediapublications.org/journals/index.php/IJ }}$ $\underline{\mathrm{R} /}$

NIEUWOUDT, S., HENNING, J. I. F. \& JORDAAN, H. (2017). 'Entrepreneurial competencies and financial performance of farmers in South Africa', South African Journal of Economic and Management Sciences, a1640. https://doi.org/10.4102/sajems.v20i1.1640

NORTON, G. W., ALWANG, J., \& MASTERS, W. A. (2014). Economics of agricultural development: world food systems and resource use (3rd ed.). Madison, Ave. New York: Routledge.

OGUNSUMI, L. O., AJAYI, A., AMIRE, C. M., \& WILLIAMS, S. (2013). Sustainability of agricultural transformation agenda: The place of rice farmers in Ogun State, Nigeria. Research on Humanities and Social Sciences, 13(3), 66-78. https://www.iiste.org/Journals/index.php/RHSS/articl e/view/7133/7415

OTEH, O. U., AGWU, N. M., OKPOKIRI, C., ANIUGA, C., \& ANI, L. O. (2018). Agricultural rice production and marketing in Nigeria: assessing regulatory agencies' role in positioning made in Nigerig Goods. Nigerian Journal, 49(2), 143-151. http://www.ajol.info/index.php/naj

OPOLOT, H. N., ISUBIKALU, P., BONTON, B., OBAA, B., \& EBANYAT, P. (2018). Influence of university entrepreneurship training on farmers' competences for improved productivity and market access in Uganda. Cogent Food and Agriculture, 4(1), 1469211. https://doi.org/10.1080/23311932.2018.1469211

OTUNAIYA, A. O., BAMIRO, O. M., \& ADEYONU A. G. (2015). Determinants of technical efficiency differentials among users and non-users of fertilizer: a case of food crop farmers in South-western Nigeria. Tropical Agriculture, 92(4), 271-281. https://journals.sta.uwi.edu/ta/

RAJABI, R., BRASHEAR-ALEJANDRO, T., \& CHELARIU, C. (2018). entrepreneurial motivation as a key salesperson competence: trait antecedents and performance consequences. Journal of Business and Industrial Marketing, 33(4), 405-416. https://www.emerald.com/insight/content/doi/10.110 8/JBIM-12-2016-0278/full/html

SAMBASIVAN, M., LI-YEN, L., CHE-ROSE, R., \& ABDUL, M. (2010). Venture performance in Malaysia: personal initiative, human capital, and competency areas of founding entrepreneurs as critical success factors. Journal of Small Business and

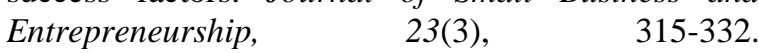
https://doi.org/10.1080/08276331.2010.10593488

SCUOTTO, V., DEL GIUDICE, M., BRESCIANI, S., \& MEISSNER, D. (2017). Knowledge-driven preferences in informal inbound open innovation modes: an explorative view on small to medium enterprises. Journal of Knowledge Management, 21(3), 640-655. https://doi.org/10.1108/JKM-102016-0465

SHER, A., MAZHAR, S., ABBAS, A., IQBAL, M. A., \& LI, X. (2019). Linking entrepreneurial skills and opportunity recognition with improved food distribution in the context of the CPEC: A Case of Pakistan. Sustainability, 11(7), 1838; https://doi.org/10.3390/su11071838

SHIH, W. L., \& TSAI, C. Y. (2016). The effects of knowledge management capabilities on perceived school effectiveness in career and technical education. Journal of Knowledge Management, 20(6), 13731392. https://doi.org/10.1108/JKM-12-2015-0515 